\title{
Evaluation of Plastic Tarps, Reduced Rates and Low-Impact Application Methods of Soil Fumigants on Loblolly Pine Seedling Production
}

\author{
Scott A. Enebak ${ }^{*}, 1$, Tom Starkey ${ }^{1}$, Marie Quicke ${ }^{1}$ and D. Paul Jackson ${ }^{2}$ \\ ${ }^{I}$ School of Forestry and Wildife Sciences, Southern Forest Nursery Management Cooperative, Forest Health Dynamics \\ Laboratory, Auburn University, AL 36849, USA \\ ${ }^{2}$ Louisiana Tech. University, Department of Agricultural Sciences, P.O. Box 10198, Ruston, LA 71272, USA
}

\begin{abstract}
Due to the world-wide phase-out of (methyl bromide) $\mathrm{MBr}$ use and new soil fumigation rules established by the US Environmental Protection Agency (EPA) to reduce bystander risk, a large-scale study comparing five fumigants using new plastics, reduced rates and low impact application techniques over three growing seasons was installed to determine the effects that these factors have on seedling quality and quantity. Seedling densities at the end of the first growing season in 2010 ranged from 190-261 seedling/ $\mathrm{m}^{2}$ with some treatments out-performing others with respect to number of seedlings. At the end of the third growing season in 2012, the best soil fumigant for producing loblolly pine (Pinus taeda L.) seedlings was chloropicrin at $280 \mathrm{~kg} / \mathrm{h}$ and $\mathrm{MBr}$ at $168 \mathrm{~kg} / \mathrm{h}$ under totally impervious film (TIF). Overall, seedling root length, surface area, root diameter and root tips were similar to the standard $\mathrm{MBr} 280$ treatment for all soil fumigants except for the Chlor 60 treatments under high density polyethylene (HDPE) plastic. The numbers of Culls was less with the higher rates and there was a corresponding increase in the number of Grade 1 and Grade 2 seedlings for each soil fumigant. These trials indicate that, while not the perfect replacement in all nursery soils, seedling production is still possible without $\mathrm{MBr}$ if alternatives such as chloropicrin are used and managers pay close attention to weed and nematode pests that are less susceptible to chloropicrin than $\mathrm{MBr}$. Higher rates of each soil fumigant were better than the lower rates.
\end{abstract}

Keywords: Soil fumigation, bystander risk, virtually impermeable film, chloropicrin, Pinus taeda, buffer zones.

\section{INTRODUCTION}

Fumigation with methyl bromide (MBr) mixtures has been the most commonly used method for producing high quality, pest-free forest-tree seedlings in the southeastern United States [1]. In 2006, the EPA began the process of reviewing the safety of soil fumigants in an attempt to mitigate bystander exposure. This process took into consideration application methods, soils, compounds, rates, crops, etc. and developed rules on usage and application methods as part of the reregistration of each soil fumigant. The compounds examined in this reregistration process included chloropicrin, dazomet, metam/potassium sodium, methyl bromide, 1,3-dichloropropene $\left(\right.$ Telone $\left.^{\circledR}\right)$, methyl isothiocyanate (MITC) and iodomethane. Similar risk assessment tools and methods were used for all fumigants and risk management approaches were consistent across all soil fumigants $[2,3]$.

Risk assessment took into account new soil flux data, information on seedling production systems, identification of high barrier tarps, and evaluation of new technologies, that resulted in an amended soil Reregistration Eligibility

*Address correspondence to this author at the Southern Forest Nursery Management Cooperative, Forest Health Dynamics Laboratory, School of Forestry and Wildlife Sciences, 602 Duncan Drive, Auburn University, Alabama, 36849, USA; Tel: 334.844.1028; E-mail: enebasa@auburn.edu
Decision (RED) in May 2009. The REDs include buffer zones, posting requirements, agricultural worker protection, applicator and handler training programs, tarp perforation and removal, good agricultural practices, application methods/practices and rate restrictions, new restricted-use designation for dazomet, site-specific fumigation plans, emergency preparation and response requirements, compliance assistance and assurance measures, and community outreach and education programs [4]. These new rules will change the way nurseries use soil fumigants as they take into account buffer tables, new plastic tarp technologies that allow the gluing of high barrier plastics (virtually or totally impermeable films - VIF or TIF), and various soil credits that could allow nurseries to continue their use of soil fumigants in the production of forest-tree seedlings with minimal disruptions and loss of production acreage.

As part of the USDA ARS Areawide MBr alternative program, these trials were a large-scale study comparing soil fumigants using the new plastics, reduced rates and low impact coulter injection application techniques over three growing seasons to determine what effects these reduced rates and different plastics (required by the new soil fumigation rules) may have on seedling quality and quantity. Information gathered from these studies will be used in the next round of soil fumigation regulations as EPA plans to consider the soil fumigants again during the Registration Review that begins in 2013. 
Table 1. MBr Alternative Soil Fumigants and Rates Used in the 2010-2012 Reduced Rate Trial at Camden, AL

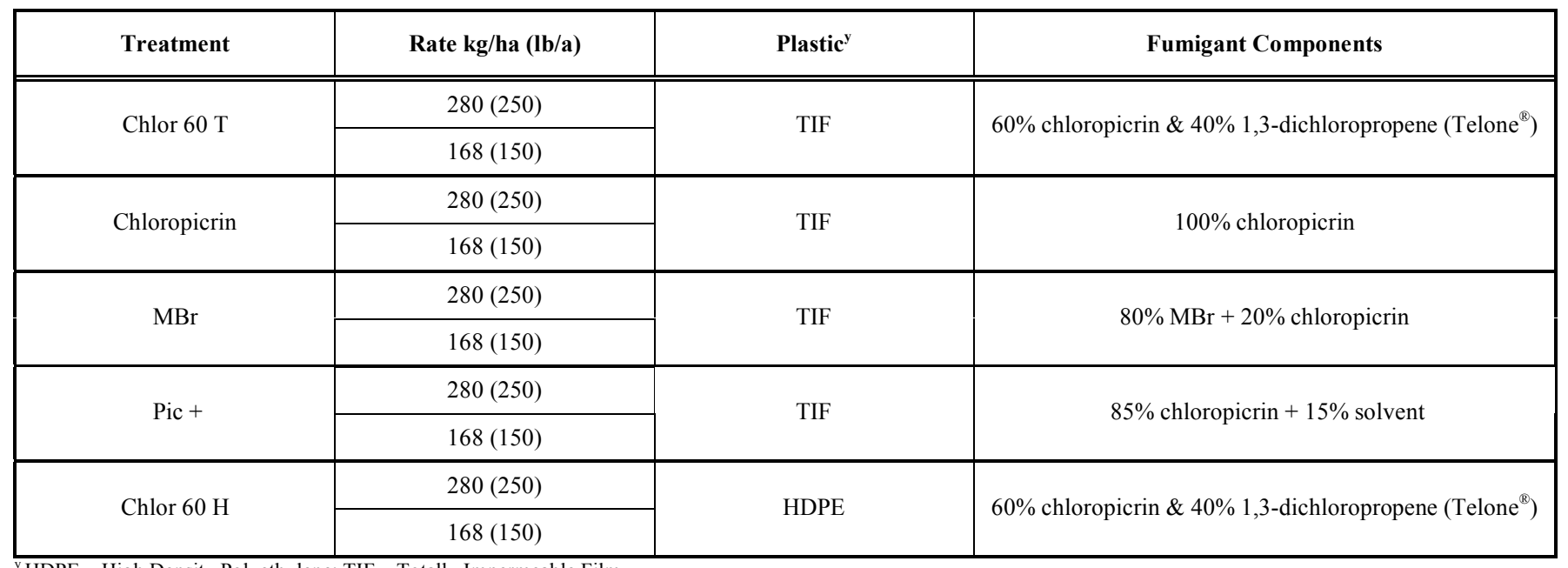

${ }^{y} \mathrm{HDPE}=$ High Density Polyethylene; TIF = Totally Impermeable Film.

\section{MATERIALS AND METHODS}

\section{Soil Fumigants}

The forest-tree nursery was located in Wilcox County, Alabama, $\left(32^{\circ} 03^{\prime} 53^{\prime \prime} \mathrm{N} ; 87^{\circ} 20^{\prime} 57^{\prime \prime} \mathrm{W}\right)$ that is primarily a Lenior silt loam. The nursery comprises 65 ha and has been in use since 1979 running a 3-1 rotation (3 seedling crops to $1 \mathrm{yr}$ fallow/cover). Seedling production is 40 million plus conifer bareroot 1-0 seedlings annually (seedlings grown and shipped in the same season). Included in this trial were four soil fumigation treatments that were selected from previous Southern Forest Nursery Management Cooperative fumigation studies under two rates and using two application methods which had never been tested previously in the production of forest-tree seedlings (Table 1). The new application technique examined Chlor 60 as a soil fumigant at two rates that were applied using a no-till coulter injection method with plots covered with a $1 \mathrm{~mm}$ High Density Polyethylene (HDPE) plastic. All other soil fumigants were shank injected and covered with Totally Impermeable Film (TIF) under the environmental conditions in Table 2. The experimental area occupied approximately 4 ha $(10$ a) and the trial was laid out in ten nursery production units that consisted of nine seedling beds between the irrigation pipelines with each bed being approximately $170 \mathrm{~m} \times 1.2 \mathrm{~m}$. The experiment was a randomized complete block design replicated four times with each treatment being $85 \mathrm{~m}$ long. Each 9-bed nursery unit included 2 soil fumigation treatments. In order to test different plastic requirements, the Chlor $60 \mathrm{H}$ treatments could not be placed with the other soil fumigants. After fumigation, and in each of the three growing seasons (2010, 2011 and 2012), a single family of loblolly pine (Pinus taeda L.) seed was sown at the same rate in the fumigated area. Seedlings in the trial area were maintained using standard nursery cultural practices (fertilization, irrigation, pest management, etc.) until lifting took place each fall. After lifting the seedlings in the winter (Nov-Dec), the treatment area was left fallow and prepared for sowing the following spring (April).
Table 2. Site Information for the 2010-2012 Reduced Rate Trial at the Pine Hill Forest-Tree Nursery in Camden, $\mathbf{A L}$

\begin{tabular}{|l|l|}
\hline \multicolumn{1}{|c|}{ Trial Parameter } & \multicolumn{1}{|c|}{ Pine Hill Nursery, Camden AL } \\
\hline \hline Fumigation date & March 23,2010 \\
\hline Fumigation types & $\begin{array}{l}\text { A. Shank injected; broadcast/with TIF flat tarp } \\
\text { B. No-till coulter injected; broadcast/with } \\
\text { HDPE flat tarp }\end{array}$ \\
\hline Experimental area & 4 ha $(10$ a) \\
\hline Air temperature & $16-25^{\circ} \mathrm{C}\left(55-73{ }^{\circ} \mathrm{F}\right)$ \\
\hline Wind speed & $5-10 \mathrm{~km} / \mathrm{h}(0-10 \mathrm{mph})$ \\
\hline Soil moisture & $7.6 \%$ \\
\hline Soil series & Lenoir silt loam \\
\hline Plastic tarps in place & 14 days \\
\hline
\end{tabular}

\section{Seedling Quality and Quantity}

The effect of the soil fumigants on seedling densities and growth characteristics was assessed in four subplots $(1.2 \mathrm{~m} \mathrm{x}$ $0.3 \mathrm{~m})$ per treatment plot at $7 \mathrm{wk}$ post-sowing, mid-summer (15 wk post-sowing) and just prior to lifting in the fall (26 wk post-sowing) in 2010, 2011 and 2012, respectively. Twenty to 35 loblolly pine seedlings per subplot were collected in the fall of each growing season and returned to the laboratory at Auburn University for analysis. Seedling root collar diameter (RCD), shoot height and seedling dry weight (biomass) was measured for each seedling as well as overall root growth. For root morphology, 10 seedlings per subplot were examined for root length, root surface area, average root diameter and the number of root tips using WinRhizo $^{\circledR}$ software by Regents Instruments Inc., Quebec, Canada.

\section{Soilborne Trichoderma and Nematodes}

Throughout the three growing seasons, soil samples were collected from the center seedling bed of each treatment: at pre-sowing, post-sowing, mid-summer and just prior to 
seedling lifting in November of each growing season. Half of each soil sample was sent to the Soils Laboratory at Auburn University for a quantitative assessment of soil-borne pathogenic nematodes, the remaining half of the sample was used to determine soilborne fungi levels by plating onto Trichoderma-selective media [5].

Analyses were carried out using the Statistical Analysis System [6]. Analysis of variance (ANOVA) was performed using the PROC GLM function to test for treatment differences at an alpha level of 0.05 . Both Duncan (within treatment) and Dunnett's paired T-test was performed using $\mathrm{MBr} 280$ as the standard nursery treatment.

\section{RESULTS}

\section{Seedling Quality and Quantity}

When comparing the various treatments using Dunnett's paired T-test, none of the treatments were significantly better than the standard $\mathrm{MBr} 280$ treatment with respect to seedling densities for the three growing seasons (Table 3). Seedling densities at the end of the first growing season in 2010 ranged from 190-261 seedling $/ \mathrm{m}^{2}$ with some treatments outperforming others with respect to seedling numbers; for example, at the high rate, Chlor 60 under both HDPE and TIF produced significantly more seedlings than Chloropicrin and Pic+. Similar results were observed for the 2011 growing season, however, seedling densities in the Chlor 60 $\mathrm{H}$ treatment under HDPE plastic were significantly less than the Chlor $60 \mathrm{~T}$ at the lower rate (Table 3). At the end of the third growing seasons in 2012, the best soil fumigant for producing loblolly pine seedlings was Chloropicrin at 280 $\mathrm{kg} / \mathrm{h}$ and $\mathrm{MBr}$ at $168 \mathrm{~kg} / \mathrm{h}$ under TIF (Table 3).

Table 3. Loblolly Pine Seedling Density at Lifting Over Three Growing Seasons (2009-2011) for the Reduced Rate Trial at the Pine Hill Forest-Tree Nursery in Camden, AL

\begin{tabular}{|c|c|c|c|c|}
\hline \multirow{2}{*}{ Treatment } & \multirow{2}{*}{$\begin{array}{c}\text { Rate kg/ha } \\
\text { (lb/a) }\end{array}$} & \multicolumn{3}{|c|}{ Seedling Densities $\left(\mathbf{m}^{2}\right)$} \\
\cline { 3 - 5 } & & $\mathbf{2 0 1 0}^{\mathbf{x}}$ & $\mathbf{2 0 1 1}$ & $\mathbf{2 0 1 2}$ \\
\hline \hline \multirow{2}{*}{ Chlor 60 T } & $280(250)$ & $261.6 \mathrm{a}$ & $303.5 \mathrm{abc}$ & $237.9 \mathrm{ab}$ \\
\cline { 2 - 5 } & $168(150)$ & $223.9 \mathrm{bcd}$ & $316.5 \mathrm{a}$ & $242.2 \mathrm{ab}$ \\
\hline \multirow{2}{*}{ Chloropicrin } & $280(250)$ & $199.1 \mathrm{de}$ & $282.0 \mathrm{abc}$ & $257.3 \mathrm{a}$ \\
\cline { 2 - 5 } & $168(150)$ & $191.6 \mathrm{e}$ & $278.8 \mathrm{abc}$ & $232.5 \mathrm{ab}$ \\
\hline \multirow{2}{*}{$\mathrm{MBr}$} & $280(250)$ & $233.6 \mathrm{abc}$ & $287.4 \mathrm{abc}$ & $234.7 \mathrm{ab}$ \\
\cline { 2 - 5 } & $168(150)$ & $217.4 \mathrm{cde}$ & $272.3 \mathrm{abc}$ & $257.3 \mathrm{a}$ \\
\hline \multirow{2}{*}{ Pic +} & $280(250)$ & $253.0 \mathrm{ab}$ & $313.2 \mathrm{ab}$ & $234.7 \mathrm{ab}$ \\
\cline { 2 - 5 } & $168(150)$ & $190.5 \mathrm{e}$ & $268.0 \mathrm{bc}$ & $216.4 \mathrm{ab}$ \\
\hline \multirow{2}{*}{ Chlor 60 H } & $280(250)$ & $247.6 \mathrm{abc}$ & $261.6 \mathrm{c}$ & $180.8 \mathrm{~b}$ \\
\cline { 2 - 5 } & $168(150)$ & $261.6 \mathrm{a}$ & $264.8 \mathrm{c}$ & $179.8 \mathrm{~b}$ \\
\hline LSD (0.05) & & $(6.8)$ & $(5.3)$ & $(5.9)$ \\
\hline
\end{tabular}

${ }^{x}$ Means (within a column) for each year followed by the same letter are not significantly different based on Duncan's Multiple Range Test $(\mathrm{p} \leq 0.05)$.

Differences in seedling root collar diameters $(\mathrm{RCD})$ among the soil fumigants tested at the Pine Hill nursery were observed only during the first growing season with Chloropicrin $168 \mathrm{~kg} / \mathrm{ha}$ treated soils producing significantly larger seedling diameters over the standard $\mathrm{MBr} 280$ soil treatment (Table 4). Chlor 60 treatments under both the HDPE and TIF produced some of the smallest root collar diameters of all the soil fumigants tested. These differences in RCDs were not maintained for the second and third growing seasons in 2011 and 2012 as all treatments resulted in similar RCDs (Table 4). Seedling RCDs declined for all treatments over the three-year rotation due to the buildup of soilborne pests and weeds over time.

Table 4. Loblolly Pine Seedling Root Collar Diameter at Lifting Over Three Growing Seasons (2010-2012) for the Reduced Rate Trial at the Pine Hill Forest-Tree Nursery in Camden, AL

\begin{tabular}{|c|c|c|c|c|}
\hline \multirow{2}{*}{ Treatment } & \multirow{2}{*}{ Rate kg/ha (lb/a) } & \multicolumn{3}{|c|}{ Root Collar Diameter (mm) } \\
\cline { 3 - 5 } & & $\mathbf{2 0 1 0}^{\mathbf{x}}$ & $\mathbf{2 0 1 1}$ & $\mathbf{2 0 1 2}$ \\
\hline \hline \multirow{2}{*}{ Chlor 60 T } & $280(250)$ & $3.9 \mathrm{bcd}$ & $3.6 \mathrm{a}$ & $3.6 \mathrm{a}$ \\
\cline { 2 - 5 } & $168(150)$ & $4.2 \mathrm{abc}$ & $3.5 \mathrm{a}$ & $3.4 \mathrm{a}$ \\
\hline \multirow{2}{*}{ Chloropicrin } & $280(250)$ & $4.3 \mathrm{ab}$ & $3.6 \mathrm{a}$ & $3.6 \mathrm{a}$ \\
\cline { 2 - 5 } & $168(150)$ & $4.6 \mathrm{a} *$ & $3.5 \mathrm{a}$ & $3.5 \mathrm{a}$ \\
\hline \multirow{2}{*}{$\mathrm{MBr}$} & $280(250)$ & $3.9 \mathrm{bcd}$ & $3.6 \mathrm{a}$ & $3.6 \mathrm{a}$ \\
\cline { 2 - 5 } & $168(150)$ & $4.1 \mathrm{abc}$ & $3.7 \mathrm{a}$ & $3.4 \mathrm{a}$ \\
\hline \multirow{2}{*}{ Pic +} & $280(250)$ & $4.0 \mathrm{bcd}$ & $3.4 \mathrm{a}$ & $3.6 \mathrm{a}$ \\
\cline { 2 - 5 } & $168(150)$ & $4.2 \mathrm{abc}$ & $3.4 \mathrm{a}$ & $3.5 \mathrm{a}$ \\
\hline \multirow{2}{*}{ Chlor 60 H } & $280(250)$ & $3.8 \mathrm{~cd}$ & $3.6 \mathrm{a}$ & $3.7 \mathrm{a}$ \\
\cline { 2 - 5 } & $168(150)$ & $3.5 \mathrm{~d}$ & $3.2 \mathrm{a}$ & $3.6 \mathrm{a}$ \\
\hline LSD (0.05) & & $(0.56)$ & $(0.38)$ & $(0.33)$ \\
\hline
\end{tabular}

Treatment mean (within a column) was significantly different from $\mathrm{MBr} 280$ based on Dunnett's t-Test $(\mathrm{p} \leq 0.05)$

${ }^{\mathrm{x}}$ Means (within a column) for each year followed by the same letter are not significantly different based on Duncan's Multiple Range Test $(\mathrm{p} \leq 0.05)$.

Overall, seedling root architecture and root morphology as measured by root length, surface area, root diameter and root tips were similar to the standard $\mathrm{MBr} 280$ treatment for all soil fumigants except for the Chlor 60 treatments under HDPE plastic in 2010 (Table 5). Both rates of Chlor 60 tended to have shorter roots and fewer root tips than $\mathrm{MBr}$ 280. Generally, first year soil fumigation results in larger seedlings, however, as far as an $\mathrm{MBr}$ alternative, all soil fumigant alternatives performed as well as $\mathrm{MBr}$ across all the root morphology measurements at this nursery in 2011. Like that of RCD and time since soil fumigation, root characteristics tended to decrease over the 2010 to 2011 growing season. Unfortunately, root architecture data was not collected in 2012.

The root weight ratio (RWR) of seedlings grown in the different soil treatments resulted in differences only during the first growing season; when comparing the lower rate of Chlor $60 \mathrm{H}$ vs Chloropicrin (Table 6). The RWR is defined as the weight of the roots divided by the total seedling weight; an optimum seedling has a root weight ratio of $>27 \%$. Seedlings with a higher RWR have better survival and growth after outplanting. While none of the treatments 
Table 5. Loblolly Pine Seedling Root Morphology at Lifting Over Three Growing Seasons (2010-2012) for the Reduced Rate Trial at the Pine Hill Forest-Tree Nursery in Camden, AL

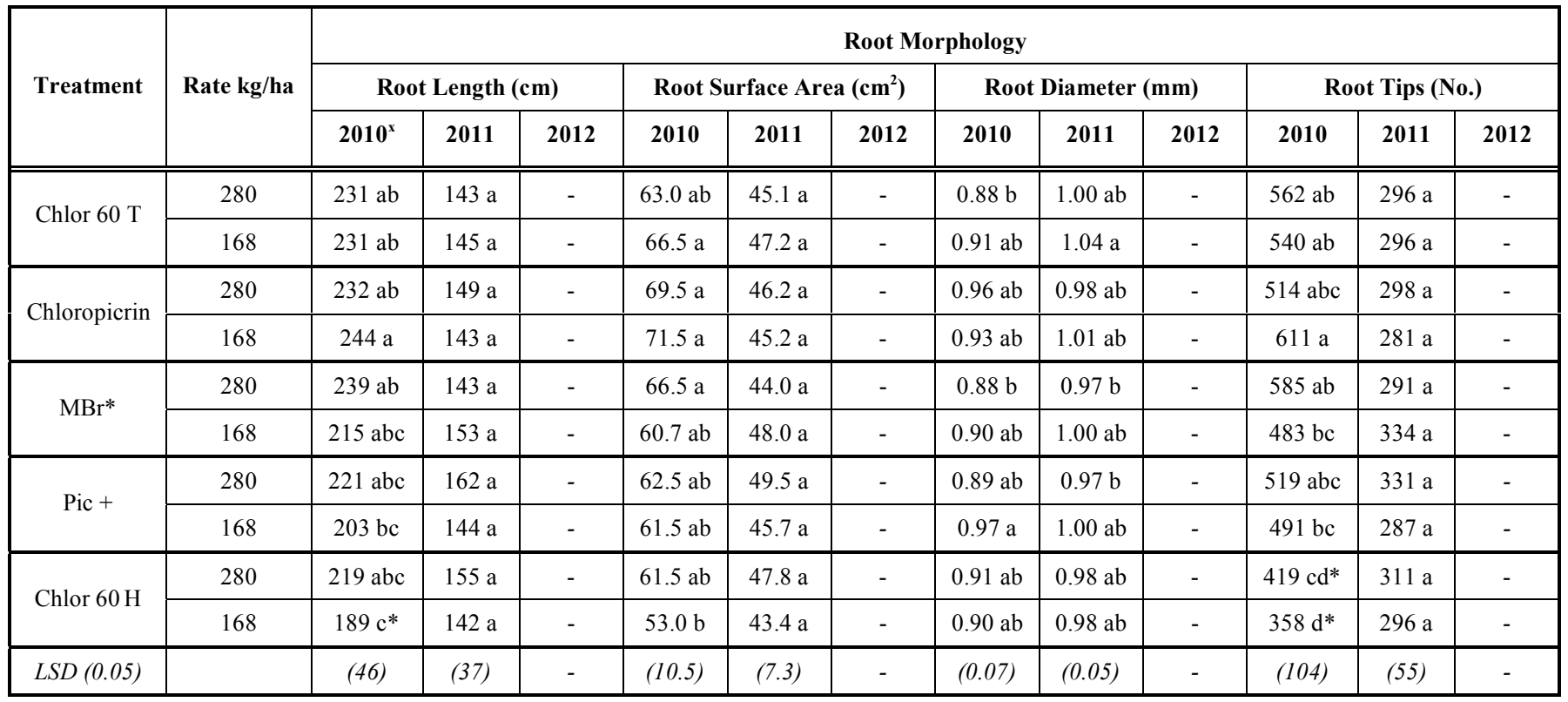

*Treatment mean (within a column) was significantly different from $\mathrm{MBr} 280$ based on Dunnett's t-Test ( $\mathrm{p} \leq 0.05)$.

${ }^{\mathrm{x}}$ Means (within a column) for each year followed by the same letter are not significantly different based on Duncan's Multiple Range Test ( $\mathrm{p} \leq 0.05$ ).

resulted in the optimum RWR, a number of factors affect RWR, including the time of lifting, growing density, the time of root pruning, irrigation and fertilization. For these trials, all of the $\mathrm{MBr}$ alternatives had similar RWR compared to the $\mathrm{MBr}$ control indicating that the alternatives were not detrimental to root growth that could affect seedling survival after outplanting.

Table 6. Loblolly Pine Seedling Root Weight Ratios at Lifting Over Three Growing Seasons (2009-2011) for the Reduced Rate Trial at the Pine Hill Forest-Tree Nursery in Camden, AL

\begin{tabular}{|c|c|c|c|c|}
\hline \multirow{2}{*}{ Treatment } & \multirow{2}{*}{ Rate kg/ha } & \multicolumn{3}{|c|}{ Root Weight Ratio (\%) } \\
\cline { 3 - 5 } & & $\mathbf{2 0 1 0}^{\mathbf{x}}$ & $\mathbf{2 0 1 1}$ & $\mathbf{2 0 1 2}$ \\
\hline \hline \multirow{2}{*}{ Chlor 60 T } & 280 & $0.15 \mathrm{ab}$ & $0.16 \mathrm{a}$ & $0.13 \mathrm{a}$ \\
\cline { 2 - 5 } & 168 & $0.15 \mathrm{ab}$ & $0.16 \mathrm{a}$ & $0.13 \mathrm{a}$ \\
\hline \multirow{2}{*}{ Chloropicrin } & 280 & $0.15 \mathrm{ab}$ & $0.15 \mathrm{a}$ & $0.13 \mathrm{a}$ \\
\cline { 2 - 5 } & 168 & $0.14 \mathrm{~b}$ & $0.15 \mathrm{a}$ & $0.13 \mathrm{a}$ \\
\hline \multirow{2}{*}{$\mathrm{MBr}$} & 280 & $0.16 \mathrm{ab}$ & $0.15 \mathrm{a}$ & $0.13 \mathrm{a}$ \\
\cline { 2 - 5 } & 168 & $0.16 \mathrm{ab}$ & $0.16 \mathrm{a}$ & $0.13 \mathrm{a}$ \\
\hline \multirow{2}{*}{$\mathrm{Pic}+$} & 280 & $0.15 \mathrm{ab}$ & $0.16 \mathrm{a}$ & $0.13 \mathrm{a}$ \\
\cline { 2 - 5 } & 168 & $0.15 \mathrm{ab}$ & $0.16 \mathrm{a}$ & $0.15 \mathrm{a}$ \\
\hline \multirow{2}{*}{ Chlor 60 H } & 280 & $0.16 \mathrm{ab}$ & $0.17 \mathrm{a}$ & $0.13 \mathrm{a}$ \\
\cline { 2 - 5 } & 168 & $0.17 \mathrm{a}$ & $0.16 \mathrm{a}$ & $0.14 \mathrm{a}$ \\
\hline$L S D(0.05)$ & & $(0.024)$ & $(0.020)$ & $(0.177)$ \\
\hline
\end{tabular}

${ }^{x}$ Means (within a column) for each year followed by the same letter are not significantly different based on Duncan's Multiple Range Test $(\mathrm{p} \leq 0.05)$.
In contrast, while RCD and RWR were similar (nonsignificant) among the 5 soil fumigants, there were significant differences among the rates used within a soil fumigant with respect to seedling grades. The number of Culls was less with the higher rates and there was a corresponding increase in the number of Grade 1 and Grade 2 seedlings for the high rate for each soil fumigant (Table 7).

\section{Soilborne Trichoderma and Nematodes}

The effect of the various soil fumigants on soilborne Trichoderma was dependent upon the compound and rate used. For example, a number of $\mathrm{MBr}$ alternatives were detrimental to Trichoderma when compared to the standard MBr 280 control (Table 8). This included a number of the Chlor 60 treatments and Pic +. By far, Chlor 60 under HDPE and TIF appeared to be detrimental to Trichoderma when compared to $\mathrm{MBr} 280$ during the third growing season in 2012 (Table 8). Trichoderma is a beneficial soilborne fungus that is used to monitor the sensitivity of the soil microorganisms to soil fumigation and therefore, suppression of Trichoderma is considered undesirable when screening soil fumigants.

Over the course of the 3-yr study, each soil fumigant plot was examined six times for both the number and species of nematodes within the soil/seedling interface. Nematode populations within the soil are rarely distributed uniformly across the nursery beds [8] and except for the pre-fumigation levels where trace levels of nematodes were recovered, all soil samples examined for nematodes were zero or nonrecoverable in $100 \mathrm{cc}$ soil samples (data not shown). Therefore, all soil fumigants were effective in eliminating 
Table 7. Seedling Grade by Treatment for the 2012 Growing Season for the Reduced Rate Trial at the Pine Hill Forest-Tree Nursery in Camden, AL

\begin{tabular}{|c|c|c|c|c|c|}
\hline \multirow{2}{*}{ Treatment } & \multirow{2}{*}{ Rate kg/ha (lb/a) } & \multicolumn{3}{|c|}{ Seedling Grades 2012 Growing Season } & \multirow{2}{*}{ Plantable } \\
\hline & & Culls $^{x}$ & Grade 2 & Grade 1 & \\
\hline \multirow{2}{*}{ Chlor $60 \mathrm{~T}$} & $280(250)$ & $29 \%$ & $62 \%$ & $9 \%$ & $71 \%$ \\
\hline & $168(150)$ & $35 \%$ & $57 \%$ & $8 \%$ & $65 \%$ \\
\hline \multirow{2}{*}{ Chloropicrin } & $280(250)$ & $28 \%$ & $63 \%$ & $9 \%$ & $72 \%$ \\
\hline & $168(150)$ & $36 \%$ & $57 \%$ & $6 \%$ & $61 \%$ \\
\hline \multirow{2}{*}{$\mathrm{MBr}$} & $280(250)$ & $34 \%$ & $57 \%$ & $9 \%$ & $63 \%$ \\
\hline & $168(150)$ & $41 \%$ & $56 \%$ & $3 \%$ & $59 \%$ \\
\hline \multirow{2}{*}{ Pic +} & $280(250)$ & $28 \%$ & $62 \%$ & $10 \%$ & $72 \%$ \\
\hline & $168(150)$ & $35 \%$ & $59 \%$ & $6 \%$ & $65 \%$ \\
\hline \multirow{2}{*}{ Chlor $60 \mathrm{H}$} & $280(250)$ & $21 \%$ & $73 \%$ & $6 \%$ & $79 \%$ \\
\hline & $168(150)$ & $32 \%$ & $61 \%$ & $9 \%$ & $70 \%$ \\
\hline
\end{tabular}

${ }^{x}$ Culls = Seedling RCD $<3.19 \mathrm{~mm}$, Grade $2=$ Seedling RCD $>3.20 \mathrm{~mm}$ but less than $<4.69 \mathrm{~mm}$, Grade $1=$ Seedling RCD $>4.70 \mathrm{~mm}$. Grade 1 seedlings survive $10 \%$ better than Grade Two Seedlings. Culls are not planted. Plantable $=$ Grade 1 and Grade 2 seedlings.

Table 8. Number of Trichoderma Colony Forming Units (CFUs) from Soils Collected Over Three Growing Seasons (2009-2011) for the Reduced Rate Trial at the Pine Hill Forest-Tree Nursery in Camden, AL

\begin{tabular}{|c|c|c|c|c|c|c|c|}
\hline \multirow{2}{*}{ Treatment } & \multirow{2}{*}{ Rate kg/ha } & \multicolumn{6}{|c|}{ Trichoderma spp (CFUs / mg soil) } \\
\hline & & June $^{\mathrm{x}}$ & Dec & June & Dec & June & Dec \\
\hline \multirow{2}{*}{ Chlor $60 \mathrm{~T}$} & 280 & $168 \mathrm{abcd}$ & $52 \mathrm{abc}$ & $110 \mathrm{bc}$ & $77 \mathrm{ab}$ & $78 \mathrm{~b}$ & $59 \mathrm{bc}$ \\
\hline & 168 & $89 \mathrm{~cd}$ & $16 \mathrm{~cd}^{*}$ & $74 c^{*}$ & $51 \mathrm{~b}^{*}$ & $70 \mathrm{~b}$ & $44 \mathrm{bc}^{*}$ \\
\hline Chloropicrin & 168 & 146 abcd & $39 \mathrm{bcd}$ & $91 c^{*}$ & $76 a b$ & $82 \mathrm{ab}$ & $82 \mathrm{ab}$ \\
\hline \multirow{2}{*}{$\mathrm{MBr}$} & 280 & $209 \mathrm{ab}$ & $80 \mathrm{a}$ & $176 \mathrm{a}$ & $98 \mathrm{a}$ & $127 \mathrm{a}$ & $112 \mathrm{a}$ \\
\hline & 168 & $178 a b c$ & $44 \mathrm{abcd}$ & $155 \mathrm{ab}$ & 99 a & $87 \mathrm{ab}$ & $56 \mathrm{bc}$ \\
\hline $\mathrm{Pic}+$ & 280 & $198 \mathrm{abc}$ & $64 \mathrm{ab}$ & $109 \mathrm{bc}$ & $72 \mathrm{ab}$ & $70 \mathrm{~b}$ & $66 \mathrm{bc}$ \\
\hline$L S D(0.05)$ & & $(100)$ & (33) & $(52)$ & $(27)$ & (43) & (40) \\
\hline
\end{tabular}

${ }^{*}$ Treatment mean (within a column) was significantly different from $\mathrm{MBr} 280$ based on Dunnett's t-Test $(\mathrm{p} \leq 0.05)$.

${ }^{\mathrm{x}}$ Means (within a column) for each year followed by the same letter are not significantly different based on Duncan's Multiple Range Test ( $\mathrm{p} \leq 0.05$ ).

nematode populations during the first growing season which were maintained during the 3 -yr rotation.

\section{DISCUSSION}

The true test of an $\mathrm{MBr}$ alternative is its performance during the second and third growing season where treatment differences usually begin to appear as disease, weed, and nematode pressures increase. Based on these trials, those soil fumigants with chloropicrin were similar to $\mathrm{MBr}$ and appear to be the most useful in controlling pests and producing quality seedlings. Historically, the standard soil fumigation treatment was $\mathrm{MBr}$ applied at $448 \mathrm{~kg} / \mathrm{h}$ (400 lb/ac) $(98 \%$ $\mathrm{MBr} \& 2 \%$ chloropicrin) under HDPE [3]. New rules governing the use of soil fumigants no longer allows either the amount $(448 \mathrm{~kg} / \mathrm{h})$ or the formulation (98/2) so foresttree nurseries will need to change their soil fumigation practices and applications rates.

Standard broadcast soil fumigation rigs use shanks to inject fumigants into the soil. One problem with shank injection rigs is that they can create chisel traces (openings or chimneys) in the soil that can allow fumigant gas to escape into the atmosphere. In an attempt to minimize fumigant loss from the chisel traces and increase fumigant 
efficacy, a coulter injected low disturbance fumigation rig was evaluated. The idea behind the low disturbance rig was to limit the upward movement of soil fumigants and decrease application rates to provide longer soil exposure rates and still achieve adequate pest (weeds, nematodes, insects, fungi) control as well as to achieve a high proportion of plantable seedlings at the end of the rotation. However, using this method, soil fumigant and plastic tarp, seedling quality and quantity was less in soils treated with Chlor 60 under the HDPE. Some possible reasons for the lack of fumigant efficacy may have been caused by one or a combinations: 1) a lower rate of fumigant (than normal) was used, 2) the fumigant injection was not deep enough on the low disturbance coulter injection rig, 3) compacting (rolling) the soil before application may have prevented gas movement laterally through the soil or 4) the HDPE plastic did not contain the soil fumigant long enough to act on the soilborne pests. Based on the poor seedling performance and negative effect on soilborne Trichoderma, the low impact soil fumigation rig is not adaptable for broadcast soil fumigation methods that are currently used in forest-tree nurseries. This type of system works well in row crops where the plastic tarp remains in place and the fumigant dispersion needs only to be within the width of the tractor path [7].

The soil type at the Pine Hill nursery (Lenior silt loam) is heavier than most forest tree nurseries and generally has not resulted in production issues to nematode populations [8]. This was evident in the nematode populations monitored that were either trace or non-detectable throughout the three growing seasons (data not shown). Therefore, the lack of nematode pressure would not require the use of soil fumigants containing 1, 3-dichloropropene (Telone $\left.{ }^{(}\right)$and could favor those with more chloropicrin compounds. Nurseries with a higher sand content may need to address the potential nematode pressures if moving away from $\mathrm{MBr}$ in their soil fumigation program.

One of the unique aspects of soil fumigants currently being tested in southern forest nurseries is that they do not completely eliminate fungi. This is important since previous research has shown that Trichoderma is an important soilborne fungus necessary for proper pine seedling growth $[9,10]$. In these trials, the population levels of non-target soilborne fungi rebounded with all soil fumigants except for Chlor 60 under HDPE (Table 8). Previous Nursery Cooperative research has shown that Trichoderma was not as sensitive to Chlor 60 as to dazomet and methyl iodide [11, 12]. These two soil fumigants significantly reduced the levels of beneficial fungi which remained after two growing seasons [13]. Why Chlor 60 under HDPE suppressed Trichoderma in these trials is unknown, but may be due to the soil preparation process prior to treatment that allowed other soil fungi to out compete.

One of the primary reasons for determining the effects of these soil fumigants on root architecture is that a more fibrous root system increases the chance of seedling survival in the field [14-16]. The effect of the soil fumigant on seedling growth was dependent upon the year and the fumigant, however, Chlor 60 under HDPE resulted in significantly smaller root mass in 2010 when compared to the standard $\mathrm{MBr} 280$ control. Over the three year period, treatment differences were not observed, and in 2012 a miscommunication resulted in no data collected. While frustrating, based on previous work it is unlikely that treatment differences would have been observed among the soil fumigants after three years [17,18]. For the 2010 and 2011 growing seasons, the seedling densities and root characteristics with chloropicrin were encouraging using the reduced rates (280 and $168 \mathrm{~kg} / \mathrm{ha})$ as the previously recommended rate of $336 \mathrm{~kg} / \mathrm{ha}[3,19]$ and the buffer zone restrictions under current soil fumigation practices in the US could limit the use of chloropicrin. These trials show that the use of chloropicrin at 280 and $168 \mathrm{~kg} / \mathrm{ha}$ under TIF, a $16 \%$ reduction in active ingredient, can still produce plantable seedlings (Tables $\mathbf{4}$ and 7).

One of the most important aspects of seedling quality is a plantable seedling with an RCD greater than $3.19 \mathrm{~mm}$. Forest-tree seedlings are sometimes graded into Culls, Grade 1 and Grade 2 based on root collar diameter (Culls = Seedling $\mathrm{RCD}<3.19 \mathrm{~mm}$, Grade $2=$ Seedling $\mathrm{RCD}>3.20$ $\mathrm{mm}$ but less than $<4.69 \mathrm{~mm}$, Grade $1=$ Seedling $\mathrm{RCD}>$ $4.70 \mathrm{~mm}$ ). Generally, Grade 1 seedlings have increased survival and growth over Grade Two Seedlings and Culls are not planted [20]. While there were no differences among treatments with respect to average RCD (Table 4), there were significant differences among the treatments with respect to rates within each soil fumigant. In all cases, the higher rate resulted in less Culls, and more Grade 2 and Grade 1 seedlings than the corresponding lower rate within a soil fumigant (Table 7). One of the more promising $\mathrm{MBr}$ alternatives was Pic + at $280 \mathrm{~kg} / \mathrm{ha}$ which had the greatest number of Grade 1 seedlings.

The wide-spread use of $\mathrm{MBr}$ has minimized extensive seedling losses due to soilborne pathogenic fungi [19]. Pythium still can cause damping-off problems in the early spring and is often limited to areas of poor drainage and standing water [21]. The soil-type at the Pine Hill nursery is conducive to damping-off caused by Pythium early in the growing season. Rhizoctonia can appear in nurseries both as root decay and as foliage blight, especially in second-year crops post fumigation as the fungus increases over the first growing season [22]. What will happen to nurseries 8 years post $\mathrm{MBr}$ ban is unknown, but at least for this 3-yr trial, soilborne pathogens did not appear to affect seedling production.

\section{CONCLUSIONS}

By far the best $\mathrm{MBr}$ alternatives tested were $\mathrm{Pic}+$, Chloropicrin and Chlor 60 with all three soil fumigants controlling soilborne nematodes and producing quality seedlings for outplanting and reforestation programs. While many nursery managers would prefer to use $\mathrm{MBr}$ in perpetuity to grow forest-tree seedlings, $\mathrm{MBr}$ will eventually be unavailable and each nursery manager will need to identify the best alternative for their nursery conditions. The final decision when selecting an $\mathrm{MBr}$ alternative needs to take into consideration the ability of the soil fumigant to work under individual nursery soil conditions and the impact of the new soil fumigation rules have on each individual nursery. These trials at the Pine Hill Nursery in Camden AL, while not the perfect replacement, seedling production is still possible without $\mathrm{MBr}$ if compounds such as chloropicrin are used and the reduced rates of 250 and $168 \mathrm{~kg} / \mathrm{ha}$ under TIF. 


\section{CONFLICT OF INTEREST}

The authors confirm that this article content has no conflict of interest.

\section{ACKNOWLEDGEMENTS}

Declared none.

\section{REFERENCES}

[1] Jang E, Wood WS, Dorschner K, et al. Methyl bromide phase out in the US: Impact and alternatives, In: USDA workshop on alternatives for methyl bromide. Crystal City, VA 1993.

[2] South DB, Enebak SA. Integrated pest management practices in southern pine nurseries. New For 2005; 31: 1-19.

[3] South DB, Carey WA, Enebak SA. Chloropicrin as a soil fumigant in forest nurseries. For Chron 1997; 73: 489-94.

[4] EPA 2012. Implementation of Risk Mitigation Measures for Soil Fumigant Pesticides. Available at: http://www.epa.gov/pesticide s/reregistration/soil_fumigants/

[5] Elad Y, Chet I, Henis Y. A selective medium for improving quantitative isolation of Trichoderma spp. from soil. Phytoparasitica 1981; 9: 59-67.

[6] SAS Institute. SAS/STAT Users Guide. Version $6^{\text {th }}$ ed. Cary (NC): SAS Institute INC. 1996.

[7] Chellemi DO, Mirusso J. An Apparatus to inject soil fumigants under raised, plastic-mulched beds. Appl Eng Agric 2004; 5: 585-9.

[8] Cram M, Fraedrich SW. Management options for control of a stunt and needle nematode in southern forest nurseries. In: Dumroese R K, Riley LE, Landis TD, Tech. Coords. 2005. National proceedings: Forest and Conservation Nursery Associations; 2004 July 12-15; Charleston, NC; Proc. RMRS-P-35. Fort Collins, CO: U.S. Department of Agriculture, Forest Service, Rocky Mountain Research Station 2005.

[9] Bailey BA, Lumsden RD. Direct effects of Trichoderma and Gliocladium on plant growth and resistance to pathogens. In: Harman GE, Kubicek CP, Eds. Trichoderma and Gliocladium. Bristol, Pa: Taylor and Francis, Inc. 1998; vol. 2: pp. 185-204.

[10] Mousseaux MR, Dumroese RK, James RL, et al. Efficacy of Trichoderma harzianum as a biological control of Fusarium oxysporum in container-grown Douglas-fir. N For 1998; 15:11-21.
[11] Carey WA, McCraw D, Enebak SA. Seedling production by seed treatment and fumigation treatment at the Glennville Regeneration Center in 2004. Coop Res Rep 05-04. Auburn, AL: Auburn Univ South For Nursery Manage 2005; p. 5.

[12] Starkey TE, Enebak SA. Indian Mound Nursery, Texas: methyl bromide alternative study 2005-2007. Research Report 08-07. Auburn, AL: Auburn University Southern Forest Nursery Management Cooperative 2008; p. 11.

Starkey TE, Enebak SA, McCraw D. Seedling quality and weed control with methyl bromide and methyl iodide at the Glennville Regeneration Center 2005-2006. Research Report 06-05. Auburn, AL: Auburn University Southern Forest Nursery Management Cooperative 2006; p. 5.

[14] Hatchell GE, Muse HD. Nursery cultural practices and morphological attributes of longleaf pine bare-root stock as indicators of early field performance. USDA For. Serv Res Pap SE $277 ; 1990$.

[15] Frampton J, Isik F, Goldfarb B. Effects of nursery characteristics on field survival and growth of loblolly pine rooted cuttings. South J Appl For 2002; 26: 207-13.

[16] Davis AS, Jacobs DF. Quantifying root system quality of nursery seedlings and relationship to outplanting performance. N For 2005; 30: 295-311.

[17] Enebak SA, Starkey TE, Quicke M. Effect of methyl bromide alternatives on seedling quality, nematodes and pathogenic soil fungi at the Blenheim and Trenton Nurseries in South Carolina: 2008-2009. J Hort For 2011; 3: 379-87.

[18] Enebak SA, Starkey TE, Quicke M. Effect of methyl bromide alternatives on seedling quality, nematodes and pathogenic soil fungi at the Jesup and Glennville Nurseries in Georgia: 2007-2008. J Hort For 2012; 4: 1-7.

[19] Cram M, Enebak SA, Fraedrich SW, et al. Evaluation of fumigants, EPTC herbicide and Paenibacillus macerans in the production of loblolly pine seedlings. For Sci 2007; 53: 73-83.

[20] South DB, Boyer JN, Bosch L. Survival and growth of loblolly pine as influenced by seedling grade: 13 year results. South J Appl For 1985; 92: 76-81

[21] Seymour CP, Cordell, CE. Control of charcoal root rot with methyl bromide in forest nurseries. South J Appl For 1979; 3: 104-8.

[22] Carey WA, McQuage K. Control of Rhizoctonia foliage blight by fungicides and fumigation: Lower application rates and fumigation effects. Res Rep 04-03. Auburn, AL: Auburn University Southern Forest Nursery Management Cooperative, p. 4; 2004. 